\title{
Transorganisational work and production in the creative industries
}

\author{
Doris Ruth Eikhof \\ Stirling Management School \\ Chapter for \\ Chris Bilton and Stephen Cummings \\ Handbook of Research on Creativity \\ Edward Elgar 2014
}

Academic and practitioner debates on managing creativity typically centre on how to facilitate people and groups being creative, how not to constrain their inventiveness, imagination and originality. To understand how creativity can be managed, a range of studies have focused on individual creativity, its antecedents, conducive environments and management techniques as well as potential constraints (e.g. Amabile 1996, Drazin et al. 1999, Oliver et al. (in this volume), Schiuma (in this volume), Sutton 2001). The underlying assumption of much of this debate is that management implies planning, organising and controlling processes of production and marketisation whereas working creatively requires freedom from tight schedules and space for imagination, unpredictable developments and play (e.g. Bilton and Leary 2002, Davis and Scase 2000, DeFillippi et al. 2007, see Thanem and Vaerlander in this volume for a discussion of whether office design can help provide such spaces for creativity). Where creativity is to be managed in an at least partly economic context, i.e. in relation to markets for product, finance (be it venture capital or public funding) or labour, the allegedly conflicting logics of management/business on the one hand and of creativity, artistic ambition or cultural innovation on the other tend to be the focus of the discussion. But while management and creative practice do follow different logics (Eikhof and Haunschild 2007), a growing number of studies shows that their relationship is by no means one of pure antagonism. As for instance Barrett (2004), Eikhof (2010) and Grabher (2002) show for software production, theatre and advertising, deadlines, finite budgets and management control can provide the boundaries that condense creative practice and facilitate innovative explosions and progress. Consequently, in their introduction to this volume, Bilton and Cummings expose dichotomist conceptualisations of management and creativity as too reductionist and as limiting our understanding of the real-life complexity in both management and creative practices. They call for conceptual and 
empirical approaches that capture the complexity of management and creativity.

This chapter heeds the call for an appreciation of such real-life complexity by analysing the work and production context that creativity and management are embedded in. The analysis focuses on a sector in which creativity is the key resource: the creative industries, or those industries 'supplying goods and services that we broadly associate with cultural, artistic, or simply entertainment value' (Caves 2000: 1). In these industries, constraining, let alone crushing, creativity would endanger the success of the respective creative enterprise, be it for- or not-for-profit. These industries therefore provide a particularly useful empirical setting for analysing the management of creativity in relation to its complex context of work and production.

Focusing on work and production uncovers an important aspect of managing creativity in the creative industries that has so far not been systematically addressed: the transorganisational character of work in these industries. In various ways, work and production in the creative industries transcend organisational boundaries and link the individual directly with structures at the macro-levels of field and society. Similarly, organisational practices link directly into such macro-structures, for instance where individual performance appraised in industry-wide processes of reputation-building rather than in intra-organisational exercises. The implications of transorganisational work and production in the creative industries for the management of creativity have so far not been explored, and the chapter will use the examples of recruitment and retention to discuss them. In so doing the chapter demonstrates how understanding the management of creativity requires understanding much more than an allegedly antagonistic, or at least ambiguous, relationship between management and creativity.

In order to analyse the real-life complexities of managing creativity in the creative industries, this chapter, firstly, focuses on the organisation of creative work and production. Drawing on an extensive range of empirical studies, work in the creative industries is characterised as transorganisational: as happening in and in relation to, but simultaneously transcending, organisations. Secondly, the chapter discusses how the transorganisationality of creative work and production influences the management of creative human resources. The chapter concludes by identifying avenues for future research and by discussing how findings from the creative industries can inform our understanding of creativity and management more widely. 


\section{THE ORGANISATION OF WORK AND PRODUCTION IN THE CREATIVE INDUSTRIES}

Influentially defined by the UK's Department for Culture, Media and Sport as those industries that 'have their origin in individual creativity, skill and talent' (DCMS 2001: 5), the creative industries are typically thought to include architecture and design, film, television, video, radio and publishing, fine arts, music and the performing arts, software and computer gaming, advertising and crafts (e.g. Caves 2000, DCMS 2001). Although the organisation of production across these industries varies, there is, as Hesmondhalgh (2007: 24) points out, a 'collective nature of these industries that matters' and that can thus be analysed across the creative industries. Focusing on the commonalities of these industries, several characteristics stand out: individual creativity and talent are the key resources, intellectual property rights play a crucial role, workers are driven by intrinsic motivation and the production of material outputs is overlaid by the production of meaning (e.g. Bilton 2007, Caves 2000, Hesmondhalgh 2007, Howkins 2001). For the management of creativity, however, two other features characteristic of the creative industries are more important. Firstly, the first unit of production incurs high sunk costs. Music recordings, a computer game or the first opening of an exhibition require high initial investment, only a fraction of which is required for their (mass) reproduction. Secondly, product success depends on changeable subjective taste, trends and fashions, and is difficult to engineer - a characteristic termed the creative industries' 'nobody knows' property by Caves (2000: 2). Consequently, only a small percentage of creative products are profitable. High initial sunk costs and risky product markets mean that to be viable, production in the creative industries has to be as flexible as possible: a flexible organisation of production reduces sunk costs and therefore potential losses. Constituting a significant part of the real-life context of management and creativity, the work and production context in the creative industries is thus one of a flexible organisation of production (Eikhof and Warhurst 2012). The following subsections review a range of existing empirical studies to describe this work and production context more systematically. This review focuses on three aspects: the organisation of production; the relationship between organisations, creative workers and the immediate context of production; and labour markets.

\section{Production in Collaborations}


Reviewing existing studies with respect to the organisation of production shows that the single most obvious characteristic of the creative industries is a focus on what is commonly called a project (e.g. Caves 2000, Davis and Scase 2000, Faulkner and Anderson 1987). Production and labour processes are designed to produce a certain product or service within a given period of time, which can be a fixed deadline or the achievement of a certain output. A book, a movie, a TV show, a theatre play, a painting, a sculpture, a radio show or a song can be seen as a project, and might themselves be a part of a larger project, e.g. a theatre repertoire, a TV or radio programme, a series of books or paintings. The outcome of these projects may be subject to further distribution, promotion, merchandising or exhibition, but the core process of production is designed and understood as a project, undertaken by specifically assembled teams.

In management and organisation studies, however, the term project has been colonised by the debate on project management in which 'projects are seen as tools, not as organisations' (Packendorff 1995: 324) and which focuses on the efficient use of projects as management tools (e.g. Lundin and Söderholm 1995). Alternative terms such as 'temporary organisations' (Lundin and Söderholm 1995) or 'project ecologies' (Grabher 2002) prioritise organisational and resource perspectives, respectively, over a focus on the organisation of production and work. We therefore use the term collaboration to refer to the temporary, output-defined structures of production and work in the creative industries.

Collaborations dominate production and work across all creative industries: a range of partners come together for a limited time to produce a certain creative output. In the performing arts, sequences of rehearsals from first readings to dress rehearsals including light, costumes and sound culminate in a premiere and a series of shows, after which the collaboration ends and partners disband (Broughton 2001, Dempster 2006, Eikhof 2010, Haunschild 2003, Sgourev 2011). In film, TV and radio, teams of creative professionals, technical professionals and support workers shoot or record the raw material, which is then edited, distributed to movie houses or broadcasters and released to the public. Production teams disband after the shooting/recording stage and a network of specialist subcontractors completes the subsequent stages of production. These industries are particularly indicative examples of how the 'production process is organised around those individual projects rather than any permanent production company per se' (Blair et al. 2001: 172, see also Baker and Faulkner 1991, Baumann 2002, Blair 2001, Christopherson and Storper 1989, 
Davis and Scase 2000, DeFillippi and Arthur 1998, Dex et al. 2000, Faulkner and Anderson 1987, Jones 1996, Starkey et al. 2000, Sydow and Staber 2002, Windeler and Sydow 2001). Evidence from the music and advertising industry shows that here, too, collaborations as temporary structures constitute the relevant context of work and employment (Davis and Scase 2000, Gander and Rieple 2002, Gander et al. 2007, Grabher 2002, 2004, Hesmondhalgh 1996, 2007, Lee 1995, Lopes 1992, Lorenzen and Frederiksen 2005, Petersen and Berger 1971, 1975, Thompson et al. 2007). Although stable organisations in the form of record labels and advertising agencies are important players in these industries, Grabher (2002: 247) describes a 'projectification' of advertising work and Davis and Scase (2000: 67) characterise the music industry as 'complex, network-based and built around short-term contracts'. Lastly, even in the visual arts or publishing, where creative outcomes are attributed to individuals, a closer look reveals that production is structured around temporary collaborations of, for example, freelance painters, sculptors or writers, technical support staff, gallery owners and editors (Caves 2000, Davis and Scase 2000, Granger et al. 1995, Kammertöns 2007, Stanworth and Stanworth 1997, Wijnberg and Gemser 2000). Contemporary visual artists such as Damien Hirst, Olafur Eliasson or Ron Mueck, for example, produce work that is publicised in their individual names with teams of up to 80 people (Diez 2007, Foundation Cartier pour l'art contemporain 2006, Rauterberg 2006, Timm 2007).

Depending on the type of output and the scale of the creative endeavour at hand, collaborations differ with respect to their complexity and the intensity with which individual work practices are interwoven with those of other collaborators. Even though a fiction writer, for instance, might collaborate closely with an editor, their everyday work practices will be less entwined than those of an opera director with the respective singers and musicians. Likewise, an action movie shot at several locations in parallel will require more complex schedules and communication structures than a short, one-location TV documentary. But despite these differences in complexity and intensity, the structural context of work throughout the creative industries remains temporary and output-focused and involves constantly changing teams of collaborators. Reviewing existing studies with respect to the organisation of production and work therefore exposes collaborations as a first characteristic of the context in which creativity is managed in the creative industries. 


\section{Organisations, Collaborations and Creative Workers}

In describing the organisation of creative production as collaborations, we have already alluded to the fact that the context of creativity and management in the creative industries transcends organisational boundaries. Because of this transcendence, two relationships become relevant: the employment relationship between organisations and creative workers and the relationship between organisations and collaborations.

Across creative industries the employment relationship between creative workers and organisations typically exhibits three characteristics. Firstly, these industries feature a high percentage of freelance workers and self-employment (e.g. European Commission 2006, Menger 1999). While average rates of freelance employment across all creative industries and occupations are estimated between 33 per cent and 50 per cent (e.g. Davis and Scase 2000), in industries such as film and TV up to 90 per cent of workers are freelance (Skillset 2010). The European Commission (2006: 100) concludes that 'artists (performing artists, writers, directors, visual artists, craftspeople, composers, musicians, designers and others) are usually self-employed freelancers' (see also Benhamou 2000). Secondly, when creative workers do find themselves in employment, these employment contracts tend to be temporary (European Commission 2006, Menger 1999). Often lasting only a few days or weeks (Dex et al. 2000), temporary contracts mean that many creative workers spend as much time looking for work as they spend in employment (Blair et al. 2001, Dex et al. 2000, Skillset 2008, 2010). Thirdly, creative workers are often involved in more than one collaboration at a time (Bain 2005, Blair et al. 2003, Dex et al. 2000, Menger 1999, Randle and Culkin 2009). In theatre, for instance, actors on temporary contracts with one theatre will frequently take on additional work as freelancers at the same time (Haunschild and Eikhof 2009). Similarly, Gill (2002) describes new media workers as typically working on two to three projects in parallel, none of which occupy all their time or provide all the income they need.

These three characteristics may vary across creative industries, countries or professions. For instance, because the allocation of subsidies to arts organisations and projects is organised differently in the UK and Germany, British actors, ballet dancers, singers or musicians tend to have much lower job security and higher rates of short-term, freelance employment than their German counterparts (e.g. Broughton 2001, Haak 2008). Similarly, some big broadcasting corporations still boast considerable shares of permanently 
employed creatives while in small independents the same tasks are undertaken by freelancers, temporary workers or interns with little to no employment security (Davis and Scase 2000, Hesmondhalgh 2007). However, focusing on the commonalities across the creative industries, two key points arise:

- The relationship between organisations and individuals tends to be temporary, freelance and not necessarily full-time. It is thus considerably looser than in other industries and, importantly, participation in collaborations is not necessarily linked to organisational membership.

- These loose relationships between employers and creative workers are characteristic not only for creative workers on the periphery of the production process who can easily be substituted, but also for those workers whose input is crucial to the creative outcome, such as lead actors, singers or dancers, directors or conductors.

With respect to the relationship between organisations and collaborations, it tends to be organisations that initiate collaborations and provide financial resources and organisational infrastructure. But how closely these collaborations are then integrated into any one organisation's processes and structures differs widely across the creative industries internationally. The Anglo-American film industry, for instance, comprises a complex web of large corporations, small and micro enterprises and freelance workers with one-off collaborations as their focal points. Producers initiate collaborations, but the production itself is spread across various actors and locations, all of which are only loosely linked to the producers via a network of temporary contracts. Subcontractors such as script writers, sound studios or editors use their own organisational and material infrastructure and any material resources required on set (sets, props, scaffolding, vehicles, catering, etc.) are hired from specialist companies. Although the production processes may be similar for most collaborations, they are specifically designed to meet the requirements of each individual film. Organisational processes and structures may intersect with collaborations, but are largely irrelevant: the Anglo-American film industry has become completely projectified and consists of a dynamic series of ever changing collaborations (Blair 2001, Christopherson and Storper 1989, Hesmondhalgh 2007, Paul and Kleingartner 1994).

In continental European performing arts, on the contrary, organisations play a much more prominent role (e.g. Broughton 2001, Haunschild 2003, Eikhof 2010). Stable 
organisations such as theatre, opera or ballet companies usually occupy architecturally prominent city centre premises and employ a substantive number of administrative and support staff on long-term contracts. Artistic staff such as actors, directors, stage, costumes and light designers work on contracts either for a season or for one production. Companies devise a season programme of shows, each of which constitutes a collaboration. Teams are assembled specifically for each collaboration and disband after the last performance. Typically, several collaborations run in parallel at any given time, so a season's worth of performances resembles a complex web of collaborations at different stages of development, rehearsal and exhibition. As the companies initiate, co-ordinate, resource and market these collaborations, the organisation-collaboration relationship is a comparatively close one in the performing arts. Collaborations are integrated into organisational processes and structures such as the programme of shows, rehearsal timetables or marketing and public relations activities. Although each show is produced as a distinct and idiosyncratic entity and although the performing arts are explicitly structured around these collaborations and their teams, companies as organisations dominate the industry's overall appearance.

Other creative industries occupy various places on this continuum from close to loose integration of organisations and collaborations. Similar to performing arts, collaborations in advertising are closely integrated into agencies as organisations (e.g. Davis and Scase 2000, Grabher 2002, 2004). The new media industry (e.g. Gill 2002, Pratt 2005) and Anglo-American theatre (e.g. Dempster 2006) resemble more the film industry, with collaborations only loosely linked to organisations. The TV and recorded music industries, finally, show a split structure (e.g. Baumann 2002, Davis and Scase 2000, Dex et al. 2000, Hesmondhalgh 2007, Starkey et al. 2000, Sydow and Staber 2002, Windeler and Sydow 2001). Where big broadcasting houses or record companies lead productions, collaborations are more closely intertwined with organisational structures and processes. But production in independent companies is as projectified as in the Anglo-American film industry.

Although in some industries collaborations may be more closely integrated into organisational processes, they remain distinct from these. It is an important feature of production in the creative industries that collaborations as the immediate context of production are distinct from general organisational procedures and processes. In many cases collaborations are initiated and resourced by organisations, but proceed without any 
direct interaction with organisational structures, processes and practices. To understand management and creativity in these industries we therefore need to take not only the relationship between organisations and creative workers into account, but also between organisations and the creative workers' immediate work context, the collaborations. Analysing these two types of relationships exposes comparatively loose ties between organisations, collaborations and creative workers as a second characteristic of these industries.

\section{Labour Markets}

The previous two sections revealed that work and production in the creative industries are organised in collaborations and that relationships between organisations, collaborations and creative workers are comparatively loose. Temporary constellations and loose relationships between the key actors make for a fluid and dynamic context of managing creativity in the creative industries. Who occupies which positions in this fluid and dynamic context is coordinated via the labour market. In traditional industrial production, organisations recruit the required human resources from an external labour market and screen them using various selection tools, for example interviews or psychometric tests. In addition, skilled and professional workers commonly find themselves in internal labour markets that match labour demand and supply within an organisation (Osterman 1987). Often offering promotions and career opportunities as well as a change of job, internal labour markets can help organisations retain valuable human resources. In the creative industries, however, where collaborations transcend organisational boundaries, processes of recruiting creative workers into collaborations differ markedly from such traditional matching of labour supply and demand.

Depending on the collaboration at hand, different types of inputs - creative, technical, business, administrative, support - are needed. These inputs are provided by workers with different skillsets and backgrounds who may be working as employees, freelancers or selfemployed with their own micro-enterprise or SME ('freelancers' are sole traders, whereas 'self-employed' can have employees or be part of a practice). In completely projectified industries such as film and TV where collaborations almost entirely comprise freelancers and self-employed creatives, participation in collaborations is co-ordinated via what is traditionally understood as external labour markets. Initiators of collaborations contract 
creative workers for the duration of the collaboration or for the provision of specified inputs or services, and once this duration or output is achieved, the contractual relationship ends (e.g. DeFillippi and Arthur 1998, Faulkner and Anderson 1987, Randle and Culkin 2009). Such decisions about participation in collaborations are traditional recruitment decisions in the sense that they match demand and supply for a specific quality and quantity of labour via a traditional external labour market. Notably, though, because most collaborations only last for a relatively short time, these recruitment decisions occur substantially more often than in other industries. Where, on the contrary, creative workers are employed with an organisation, for instance with an advertising agency or as ensemble members in a performing arts organisation, decisions about participation in a collaboration can be understood as casting decisions: directors or managers choose a team for a collaboration from an existing cast of employees, similar to a football manager choosing the team for a match from the full squad. In these cases, employment and participation in a collaboration overlap, but they are not synonymous; creative workers can be employed by an organisation without participating in a specific collaboration.

Neither internal casting decisions nor external recruitment are internal or external labour markets in the traditional sense. Two aspects are particularly relevant here. Firstly, even where collaborations are comparatively closely integrated with organisations and creatives work as (temporary) employees, collaborations comprise substantive shares of freelance workers. These freelance workers pose direct competition to employed creatives, most prominently in the performing arts where directors regularly favour a freelance, 'guest' actor, singer or musician over an ensemble member. Casting decisions are thus not limited to internal labour markets, but regularly transgress organisational boundaries. Secondly, the decision-makers who recruit participants into a collaboration are not necessarily members of the organisation that initiates and resources the collaboration. In film, for instance, recruitment decisions are taken by freelance heads of departments, directors and casting agencies, all of which are only loosely linked to the production company (Blair 2001, Randle and Culkin 2009). Similarly, in the performing arts freelance directors decide on the cast for operas, plays and concerts that are produced and marketed in the respective opera, orchestra or theatre company's name (Dempster 2006, Haunschild and Eikhof 2009, for media Sutton Trust 2006). To a significant degree not only the creative workers who are subject to recruitment decisions, but also the decision-makers are at best 
loosely aligned with the respective organisation. The distinction between external and internal labour markets thus becomes meaningless. Like collaborations as the immediate context of work and production, the mechanisms for co-ordinating participation in collaborations transcend organisations. With respect to the real-life complexities of management and creativity, these transorganisational labour markets therefore constitute the third relevant characteristic of creative industries.

\section{Transorganisational Work}

The previous subsections have described three characteristics of the real-life context of management and creativity in the creative industries, focusing on the organisation of production, the relationship between organisations, creative workers and the immediate context of production, and labour markets. Analysis of the creative industries with respect to these three aspects reveals three characteristics:

- Creative production and work are undertaken in temporary structures: collaborations. Workers with diverse skills and undertaking diverse tasks come together for a limited stretch of time to produce a certain project output. This output determines the processes designed for the collaboration, its duration and its cast of creative workers and other partners. As collaborations are idiosyncratically designed to suit the creative endeavour at hand, the context of management and creativity constantly changes. Importantly, collaborationspecific processes and schedules constitute the main frame of reference in which creative capacity is turned into creative output; any organisational structures or production processes are of lesser or no importance.

- Organisations, collaborations and creative workers are only loosely coupled. Organisations can be influential partners in collaborations but collaborations need not be closely linked to any one organisation or integrated with organisational processes. Likewise, creative workers do not have to be members of a particular organisation to partake in collaborations; on the contrary, organisation-individual relationships are typically governed by short-term, flexible contracts.

- Teams for collaborations are recruited via labour markets that transcend organisations. Internal and external labour markets in the traditional sense amalgamate to form transorganisational labour markets that reconcile the supply 
of creative workers with the collaboration-driven demand for creative labour.

These three characteristics - collaborations as the key context of creative work and production, loose coupling of organisations, creative workers and collaborations, and transorganisational labour markets - denote what we term the ideal type of transorganisational work. This definition highlights that work in the creative industries transcends organisations in a way that makes distinctions between internal and external workforces or labour markets obsolete. For understanding the real-life complexities of management and creativity in the creative industries, the status of creative workers as members of organisations becomes less important; it is superseded by their involvement in a series of creative collaborations. In other words: what counts in the creative industries is who is involved in which collaborations, in which role and with what success. The underlying contractual arrangements of employment or between organisations and collaborations are of, at best, secondary interest.

In the following section we will explore the implications of transorganisational work for the management of creative human resources. Before proceeding with our analysis, however, we need to draw attention to ideal types as a tool of theoretical enquiry. Following Weberian tradition, the ideal type of transorganisational work was constructed by 'abstracting and synthesising those characteristics that a set of empirical phenomena have in common' (Weber 1922/1972: 193, author's translation). Ideal types provide a theoretically guided and focused analysis of social phenomena and thus prevent empirical research from remaining a mere collection of individual case data (see also Kluge and Kelle 1999). Instead of minutely mirroring real practices of work and production in a particular creative industry's setting, the ideal type of transorganisational work offers 'a foil against which unique contextual features can be more easily seen' (Neumann 2000: 34). It is in this sense that we employ the ideal type of transorganisational work in the remainder of this chapter and suggest it be used for further empirical analysis within and outwith the creative industries.

\section{MANAGING CREATIVITY, MANAGING A TRANSORGANISATIONAL WORKFORCE}

As outlined at the beginning of this chapter and in Bilton and Cummings' introduction to the handbook (Chapter 1), management and creativity are typically discussed as antagonistic. The underlying assumption is that management's need to plan, monitor and control limits 
creative freedom and thus constrains the quality and innovativeness of creative work. While such dichotomist views have been exposed as too simplistic (e.g. Bilton 2007, Eikhof 2010, Grabher 2002), management and creative practices do indeed follow different and distinct logics, which we have elsewhere described as artistic and economic logics (Eikhof and Haunschild 2007). Balancing or reconciling these logics is crucial to managing workers in the creative industries (e.g. Bilton 2007, Davis and Scase 2000, Barrett 2004). However, analysing work in the creative industries as transorganisational opens up a range of other pertinent aspects of managing creativity. These other aspects are the focus of the following discussion.

Because creativity is provided by individuals, a substantial share of managing creativity is managing human resources. The key task of human resource management (HRM) is to ensure that, firstly, the right quality and quantity of human resources are available for production and that, secondly, this workforce converts its potential into actual productivity. A variety of HRM tools can help facilitate this task: HR planning, recruitment and selection, performance monitoring and appraisal, retention and dismissal. Notably, though, the majority of these tools are premised on a long-term perspective and assume that employees stay with organisations for at least some length of time. Traditionally, the underlying assumption of recruitment, training, performance monitoring and appraisal and retention is that the employee will remain with the respective organisation long enough for these HRM investments to pay off. In the transorganisational work and production context of the creative industries, however, organisation-individual relationships are typically neither that tight nor that stable. Organisations and individuals are only loosely connected and their relationship is typically of a temporary nature. These features of transorganisational work and production have important implications for the management of creative human resources, which will be discussed in the following.

A first major implication of transorganisational work and production is that although in the creative industries, managing creativity equals HRM, traditional systematic training approaches are absent. As short-term relationships between organisations and individuals do not allow organisations to recoup substantial training investments, on-the-job training tends to be in the form of unpaid or low-paid internships without clear pathways from education to employment. Although on-the-job training, as opposed to training provided by further and higher education institutions, is seen as vital in these industries (e.g. Grugulis 
and Stoyanova 2009, Randle and Culkin 2009), a 'grow your own' approach to creative human resources is not lucrative for most creative industries employers. Large organisations with an explicit training and development approach, such as the BBC, for instance, remain the exception. Initiatives such as the Skillset internships and Skillset Academies in the UK try to establish more systematic industry-based training schemes, but unpaid work experiences continue to dominate routes into the industry (e.g. Skillset 2010).

A second implication of transorganisational work and production for the management of creative human resources concerns retention. As unemployment is typically high in the creative industries, retaining creative workers once they have been recruited into a collaboration is typically not a problem. Instead, the focus shifts from retention in the traditional sense to securing the availability of a pool of qualified creative human resources that can be recruited into collaborations as and when needed. At this point, the recruitment mechanisms prevalent in the creative industries come into play. Recruitment into collaborations - whether, as distinguished above, as recruitment in the traditional sense or as casting decisions - is overwhelmingly through the personal networks of those who artistically/creatively lead on a collaboration. Directors and producers build a team of collaborators they either know themselves or who have come recommended by trusted third parties, be those industry insiders or agencies (e.g. Blair 2001, Haunschild and Eikhof 2009, Randle and Culkin 2009, Sutton Trust 2006). In more complex collaborations, e.g. film productions, key collaborators such as heads of camera, sound or lighting departments recruit their crew through their own networks (Blair 2001). Recruitment through personal networks serves as a quality assurance mechanism: in collaborations with tight project schedules there is little to no room for correcting appointments, so making the right recruitment choices is crucial. Personal networks supply vital information not only on whether a specific individual can do the job, but also on their work ethic and what they are like to work with (Grugulis and Stoyanova 2009). Given these recruitment practices, the success of collaborations depends on the networks of the collaborations' decision-makers and on whether these networks can draw on a broad and deep enough pool of creative human resources.

From the point of view of organisations that initiate collaborations, this dependence on the collaborations' artistic decision-makers creates an interesting shift in the management of creative human resources: the collaborations' decision-makers are often 
not members of the organisation either. Directors, producers or conductors typically work as freelancers, with contracts often not extending beyond a single collaboration. An organisation's access to the desired quality and quantity of creative resources thus depends on individuals the organisation itself has got only loose ties with. These loosely linked individuals control the organisation's access to those resources that are most crucial to its creative and therefore business success. Compared with traditional HRM, this is quite a remarkable implication of transorganisational work and production. Itself a consequence of organisations' attempts to minimise the business risks of creative production, transorganisational work and production result in organisations surrendering direct control over their core resources - a situation that runs counter to any management approach borne out of the influential resource-based view (e.g. Barney 1991, Penrose 1980), which sees tight control of core competencies and resources as crucial to organisational success.

To understand why organisations can risk such low control over core resources, the situation of individual creative workers needs to be taken into account. Two aspects are important in this regard. Firstly, the creative industries' transorganisational labour markets are fiercely competitive and constantly feature a significant over-supply of creative labour. With contracts typically short term and often limited to single collaborations, creative workers spend a substantial amount of their time looking for employment instead of actually working on collaborations. For instance, 74 per cent of film workers surveyed by Skillset (2008) had been unemployed and sought work at some stage in the 12 months prior to the survey, with 30 per cent spending a substantial 11-29 weeks out of work. Creative human resources of higher quality will be more in demand and less readily available, but overall only a small percentage of those working in the creative industries can afford to be choosy about the collaborations they will get involved in.

Secondly, because collaborations are so central to the creative industries, careers are perceived as sequences of collaborations, too: films worked on, shows starred in, exhibitions contributed to. Career success is then assessed by the artistic clout attached to these collaborations (Boutinot 2012, Cameron 1995, Faulkner and Anderson 1987, Hirsch 1972, Jones 2002): what was the respective worker's role in the collaboration, e.g. lead or supporting role, group or solo show? What is the reputation of the other collaboration partners involved, both in the absolute sense of industry-wide reputation and in relation to the creative worker in question (e.g. working with established artists reflects positively on a 
novice while a collaboration staffed with no-names can damage the good reputation of a mid-career creative)? How did critics asses the collaboration's artistic output, e.g. was it awarded any prizes or awards, featured at festivals? What genre did the collaboration's output belong to and where did it thus position its collaborators artistically within their industry? What was the audience and market response, e.g. was a computer game or advertising campaign commercially successful? Through such evaluations of collaborations a creative worker has been involved in, individual artistic reputations are built. Partly such reputations are driven by the individual desire to make a particular artistic or creative contribution to the industry (e.g. Bain 2005, Svejenova 2005). Creative workers define themselves as dedicated to specific artistic genres and creative causes, which in turn give meaning to their professional trajectories. At the same time, though, the quest to establish one's artistic reputation is linked to the need to market one's labour power (Bain 2005, Eikhof and Haunschild 2006, Haunschild and Eikhof 2009). Creative workers have to clearly stand for a certain authentic artistic contribution that decision-makers can recognise as valuable to a collaboration. A distinctive individual reputation is thus both an outcome of artistic motivations and aspirations as well as a necessity for winning opportunities to convert these motivations and aspirations into actual artistic output by participating in collaborations.

From the point of view of an organisation initiating a collaboration, this individual focus on artistic reputation is important. In order to be (artistically or commercially) successful, an organisation has to initiate collaborations that constitute an attractive opportunity to build artistic reputation. Constellations need to be attractive to creative workers generally, but in particular to those who can lead them and can recruit other creatives into the collaboration. Attracting collaboration leads is a task typically undertaken by organisations' artistic or creative directors, which means that an organisation's capacity to attract good collaborators is again dependent on a particular individual's contact book. When artistic and creative directors move, their contacts typically move with them and the organisations' standing within the respective creative industry is up for reassessment. To a certain extent such constant change induced by the merry-go-round of creative human resources is deliberate: the prevailing ethos in the creative industries is one of development, transformation and renewal, all of which are regarded as conducive to creative innovation (Boltanski and Chiapello 2005, Howkins 2001). Such beliefs might contribute to creative 
industries organisations being less concerned about the long-term retention of creative human resources in the traditional sense. But managing creative human resources in the creative industries, both in a specific collaboration and in terms of organisations initiating portfolios of collaborations, requires careful maintenance of both personal contacts and artistic reputation.

Analysing the implications of transorganisational work and production thus uncovers an important dyad for managing creativity in the creative industries: the simultaneous importance of the individual creative worker and industry-wide mechanisms of reputationbuilding. At any given time, the micro-level of the individual is directly linked into the macrolevel of the industry: individual action cannot be understood without linking it into industrywide structures of personal networks, formal and informal performance assessment and reputation-building. This micro-macro dyad is important for those managing creativity in two ways. Firstly, it has to be taken into account in the management of creative workers. How an individual creative worker will behave on a collaboration in the day-to-day running of it, how committed they will be to it, how much of their energy and creative attention they will allocate to it will depend on how that collaboration is positioned within the transorganisational, industry-wide structures of networks and reputation-building. They might have been recommended to the collaboration by an influential contact within the industry, in which case they are likely to be motivated to live up to the expectations and the trust in their creative ability expressed through that recommendation. Equally, they might in parallel be working in a second collaboration that promises comparatively higher pay-offs in terms of artistic recognition, in which case they are less likely to contribute to the first collaboration with full energy. A manager has to be able to understand such individual but transorganisational concerns in order to shape collaborations, i.e. the context of creative work, in a way that makes it attractive for the creative workers to be most dedicated to the collaboration at hand.

Secondly, the micro-macro dyad needs to be taken into account when making strategic artistic or creative decisions, such as designing programmes, commissioning work or investing in individual artists. The industry-wide networks, perceptions of artistic quality, trends or criteria for creative innovation that are crucial for such strategic management of creativity cannot be understood without recourse to individuals' creative outputs and agendas, influential judgements or personal alliances (e.g. Alvarez et al. 2005, Jones 2010). 
To appreciate, for instance, how genres, and with them individual artists, are developed, the actions of critics, patrons and other influential industry insiders or 'cultural mediators' (Bourdieu 1983a, 1983b) need to be considered. Rüling and Strandgaard Pedersen (2010), for instance, outline how film festivals can be understood as 'field-configuring events' in which the festival directors' or programming committee's programming decisions draw on existing perceptions of genres and artistic quality and at the same time challenge, confirm or alter these perceptions. In doing so, they influence both the context for individual careers and the evaluation of creative output throughout the industry. Similarly, managers need to understand the interplay of individual artists and key gatekeepers that drive the trends and form the genres a manager might want to orient production towards.

In this micro-macro dyad, organisations play a role, but not necessarily the decisive one. Individual action and industry-wide structures and processes include organisations, but they transcend them. In their daily working lives, individuals are concerned both with their immediate collaborators and with their embeddedness in the industry. Both are relevant and influence individual action at the same time. Vice versa, industry structure and action is always related to concrete individuals. This micro-macro dyad is thus a key aspect of the real-life context of managing creativity - and one that emerges from analysing work and production in the creative industries as transorganisational.

\section{CONCLUSION}

The aim of this chapter was to open up the analysis of managing creativity in a way that appropriately captured the real-life complexity of management and creativity. This analysis was deliberately situated in the creative industries, where creativity is the decisive resource and its management thus crucial to organisational success. Drawing on existing studies, the chapter has argued that work and production in the creative industries are transorganisational. Work and production are undertaken in collaborations as temporary structures that are designed towards producing a defined project output. Organisations, collaborations and creative workers are only loosely coupled, and recruitment into collaborations is via transorganisational labour markets that transcend what traditionally would be called internal and external labour markets. In a second step the chapter then analysed how the transorganisationality of creative work and production influence the management of creativity. In the creative industries, managing creativity largely means 
managing human resources, but because of the transorganisationality of creative work and production, HRM deviates from traditional HRM practices. Long-term orientations in recruitment, training, performance appraisal and retention are replaced by dynamic and flexible relationships between individuals that transcend both organisations and collaborations and are always oriented towards the industry as a whole. Analysing HRM practices in the creative industries thus revealed a context of work and production that is at the same time focused on industry-wide structures, i.e. the transorganisational structures of work and production, and on individual creative workers and decision-makers, each with their own artistic reputation. Managing creativity, both as managing individual creative workers and as strategically managing creative programmes and outputs, requires awareness of this micro-macro dyad.

Analysing management and creativity in the creative industries from the perspective of transorganisational work and production opens up two new pathways for future research into the real-life context of management and creativity. Firstly, it broadens our understanding of such management in the creative industries themselves. In creative industries research, managing creativity is predominantly discussed as balancing tensions between art and business, or artistic and economic logics. Although this aspect is clearly important for managing creativity, this chapter has demonstrated that the transorganisationality of work and production in the creative industries impacts management and creativity in ways that lie beyond balancing potential conflicts between art and business. For understanding management and creativity in their real-life context in these industries, both the relationship between art and business and the micro-macro dyad have to be taken into account. What happens at the level of individuals, organisations, projects and industries amalgamates into a complex context against which we need to understand the actions of creative workers and managers. Research into a particular collaboration, for instance the production of a show or a record, cannot be limited to the narrow empirical setting of the collaboration itself, but has to be linked into the wider industry and societal context, exploring, for instance, links between recruitment and reputation or performance and positioning in the industry.

Secondly, appreciating the implications of transorganisational work and production for management and creativity in the creative industries allows asking new questions of contexts in which the management of creativity is important, but the (potential) art- 
business conflict is not. For instance, in academia or corporate research and development, technological, scientific or intellectual creativity are vital resources. Distinguishing between the art-business relationship and the micro-macro dyad in the creative industries allows analysing which HRM practices are attributable to which influence, and can then help analyse to what extent transorganisationality of work and production impacts the management of creativity outwith the creative industries. Existing studies on knowledgeintensive work already hint at transorganisational aspects of such work, for instance with respect to employment practices or with respect to organisational knowledge creation (e.g. Carnoy et al. 1997, Cohendet and Simon 2007). Another prominent example is academia. University strategies require their researchers to collaborate with other institutions because such collaborations increase their own institutional reputation and their capacities for attracting funding. Nevertheless, in their daily operations universities often still fail to address the practicalities of staff working transorganisationally, i.e. across institutions, geographies and time zones, in a way that facilitates rather than constrains academic creativity. The perspective of transorganisational work could be used to analyse the degree to which organisational strategies of capitalising on field-wide networks of creativity and knowledge-generation need to be (and currently are) supported by administrative organisational policies and practices. Further, and similar to the creative industries, HRM in knowledge-intensive work equals the management of workers who creatively generate and apply knowledge. Again, applying a transorganisational work perspective could help better understand how such workers develop and exercise loyalties towards employers vis-à-vis, for instance, professions, and what the implications are for an organisationally driven management of creativity.

In making these two contributions to future research within and outwith the creative industries, the chapter has proposed new conceptual avenues for understanding the reallife context of management and creativity. As a conceptual perspective, transorganisational work and production allows better appreciating the complexity of managing creativity. Research using this perspective can therefore generate new understanding of the real-life practices in a substantial share of contemporary and future workplaces, and can thus provide insights that are relevant to academics and practitioners alike.

\section{REFERENCES}


Alvarez, J.L., C. Mazza, J. Strandgaard Pedersen and S. Svejenova (2005), 'Shielding idiosyncrasy from isomorphic pressures: Towards optimal distinctiveness in European film making', Organization, 12(6), 863-88.

Amabile, T. (1996), Creativity in context, New York: Westview.

Bain, A. (2005), 'Constructing an artistic identity', Work, Employment and Society, 19(1), 2546.

Baker, W.E. and R.R. Faulkner (1991), 'Role as resource in the Hollywood film industry', American Journal of Sociology , 97(2), 279-309.

Barney, J. (1991), 'Firm resources and sustained competitive advantage', Journal of Management, 17(1), 99-119.

Barrett, R. (2004), 'Working at Webboyz: An analysis of control over the software development labour process', Sociology, 38(4), 777-94.

Baumann, A. (2002), 'Informal labour market governance: The case of the British and German media production industries', Work, Employment and Society, 16, 27-46.

Benhamou, F. (2000), 'The opposition between two models of labour market adjustment: The case of audiovisual and performing arts activities in France and Great Britain over a ten year period', Journal of Cultural Economics, 24, 301-19.

Bilton, C. (2007), Management and creativity. From creative industries to creative management, Malden: Blackwell Publishing.

Bilton, C. and R. Leary (2002), 'What can managers do for creativity? Brokering creativity in the creative industries', International Jorunal of Cultural Policy, 8(1), 49-64.

Blair, H. (2001), "You're only as good as your last job": The labour process and labour market in the British film industry', Work, Employment and Society, 15(1), 149-69.

Blair, H., S. Grey and K. Randle (2001), 'Working in film. Employment in a project based industry', Personnel Review, 30(2), 170-85.

Blair, H., N. Culkin and K. Randle (2003), 'From London to Los Angeles: a comparison of local labour market processes in the US and UK film industries', International Journal of Human Resource Management, 14(4), 619-33.

Boltanski, L. and E. Chiapello (2005), The new spirit of capitalism, London: Verso.

Bourdieu, P. (1983a), The field of cultural production. Essays on art and literature, New York: Columbia University Press.

Bourdieu, P. (1983b), 'The field of cultural production, or: The economic world reversed', 
Poetics, 12, 311-56.

Boutinot, A. (2012), 'Reputation-building in the French architecture field', in C. Matthieu (ed.), Careers in the creative industries, London: Routledge, pp. 163-84.

Broughton, A. (2001), 'Collective bargaining in the arts and culture sector: an examination of symphony orchestras in Germany and the UK', European Journal of Industrial Relations, 7(3), 327-45.

Cameron, S. (1995), 'On the role of critics in the cultural industry', Journal of Cultural Economics, 19, 321-31.

Carnoy, M., M. Castells and C. Benner (1997), 'Labour markets and employment practices in the age of flexibility: A case study of Silicon Valley', International Labour Review, 136(1), 25-48.

Caves, R.E. (2000), Creative industries, Cambridge: Harvard University Press.

Christopherson, S. and M. Storper (1989), 'The effects of flexible specialization on industrial politics and the labor market: The motion picture industry', Industrial and Labor Relations Review, 42, 331-47.

Cohendet, P. and L. Simon (2007), 'Playing across the playground: Paradoxes of knowledge creation in the videogame firm', Journal of Organizational Behavior, 28(5), 587-605.

Davis, H. and R. Scase (2000), Managing creativity, Buckingham: Open University Press.

DeFillippi, R.J. and M.B. Arthur (1998), 'Paradox in project-based enterprise', California Management Review, 40(2), 125-39.

DeFillippi, R., G. Grabher and C. Jones (2007), 'Introduction to paradoxes of creativity: Managerial and organizational challenges in the cultural economy', Journal of Organizational Behavior, 28(5), 511-21.

Dempster, A. (2006), 'Managing uncertainty in the creative industries: Lessons from Jerry Springer the Opera', Creativity and Innovation Management, 15(3), 224-33.

Department for Culture, Media and Sport (DCMS) (2001), Creative industries mapping document, London: DCMS.

Dex, S., J. Willis, R. Paterson and E. Sheppard (2000), 'Freelance workers and contract uncertainty: the effects of contractual changes in the television industry', Work, Employment and Society, 14(2), 283-305.

Diez, G. (2007), 'Atelierbesuch Olafur Eliasson', ZEITmagazin Leben, 34, 40-42.

Drazin, R., M.A. Glynn and R.K. Kazanjian (1999), 'Multilevel theorizing about creativity in 
organizations: A sensemaking perspective', Academy of Management Review, 24(2), 286-307.

Eikhof, D.R. (2010), 'The logics of art: analysing theatre as a cultural field', in B. Townley and N. Beech (eds), Managing creativity: exploring the paradox, Cambridge: Cambridge University Press.

Eikhof, D.R. and A. Haunschild, A. (2006), 'Lifestyle meets market. Bohemian entrepreneurs in creative industries', Creativity and Innovation Management, 13(3): 234-241.

Eikhof, D.R. and A. Haunschild (2007), 'For art's sake! Artistic and economic logics in creative production', Journal of Organizational Behavior, 28(5), 523-38.

Eikhof, D.R. and C. Warhurst (2012), 'It's the model, stupid! Why social equalities in the creative industries are systemic', manuscript, Stirling and Sydney.

European Commission (2006), The economy of culture in Europe, Luxembourg: KEA European Affairs.

Faulkner, R.R. and A.B. Anderson (1987), 'Short-term projects and emergent careers: Evidence from Hollywood', American Journal of Sociology, 92, 879-909.

Foundation Cartier pour I"art contemporain (2006), Ron Mueck, London: Thames and Hudson.

Gander, J., A. Haberberg and A. Rieple (2007), 'A paradox of alliance management: Resource contamination in the recorded music industry', Journal of Organizational Behavior, 28(5), 607-24.

Gander, J. and A. Rieple (2002), 'Inter-organisational relationships in the worldwide popular recorded music industry', Creativity and Innovation Management, 11(4), 248-54.

Gill, R. (2002), 'Cool, creative and egalitarian? Exploring gender in project-based new media work in Europe', Information, Communication and Society, 5(1), 70-89.

Grabher, G. (2002), 'The project ecology of advertising: tasks, talents and teams', Regional Studies, 36(3), 245-62.

Grabher, G. (2004), 'Learning in projects, remembering in networks? Community, sociality, and connectivity in project ecologies', European Urban and Regional Studies, 11(2), 103-23.

Granger, B., J. Stanworth and C. Stanworth (1995), 'Self-employment career dynamics: The case of "unemployment push" in UK book publishing', Work, Employment and Society, 9(3), 499-516. 
Grugulis, I. and D. Stoyanova (2009), "“I don't know where you learn them": skills in film and TV', in A. McKinlay and C. Smith (eds) Creative labour, London: Palgrave, pp. 135-55. Haak, C. (2008), Wirtschaftliche und soziale Risiken auf den Arbeitsmärkten von Künstlern, Wiesbaden: VS Verlag für Sozialwissenschaften.

Haunschild, A. (2003), 'Managing employment relationships in flexible labour markets: The case of German repertory theatres', Human Relations, 56(8), 899-929.

Haunschild, A. and D.R. Eikhof (2009), 'Bringing creativity to market. Actors as self-employed employees', in A. McKinlay and C. Smith (eds), Creative labour. Working in the creative industries, Basingstoke: Palgrave Macmillan.

Hesmondhalgh, D. (1996), 'Flexibility, post-Fordism and the music industries', Media, Culture and Society, 15(3), 469-88.

Hesmondhalgh, D. (2007), The cultural industries, London: Sage.

Hirsch, P.M. (1972), 'Processing fads and fashions: An organization-set analysis of cultural industry systems', American Journal of Sociology, 77(4), 639-59.

Howkins, J. (2001), The creative economy, London: Penguin.

Jones, C. (1996), 'Careers in project networks: The case of the film industry', in M.B. Arthur, and D.M. Rousseau (eds), The boundaryless career. A new employment principle for a new organizational era, Oxford: Oxford University Press, pp. 58-75.

Jones, C. (2002), 'Signaling expertise: how signals shape careers in creative industries', in M. Peiperl, M. Arthur and N. Anand (eds), Career creativity: explorations in the remaking of work, Oxford: Oxford University Press.

Jones, C. (2010), 'Finding a place in history: Symbolic and social networks in creative careers and collective memory', Journal of Organisational Behavior, 31, 726-48.

Kammertöns, H.B. (2007), 'Atelierbesuch Jörg Immendorff', ZEITmagazin Leben, 24, 44-6.

Kluge, S. and Kelle, U. (1999), Vom Einzelfall zum Typus: Fallvergleich und Fallkonstrastierung in der qualitativen Sozialforschung, Opladen: Leske + Budrich.

Lee, S. (1995), 'Re-examining the concept of the "independent" record company: The case of Wax Trax! Records', Popular Music, 14(1), 13-31.

Lopes, P.D. (1992), 'Innovation and diversity in the popular music industry, 1969 to 1990', American Sociological Review, 57, 56-71.

Lorenzen, M. and L. Frederiksen (2005), 'The management of projects and product experimentation: Examples from the music industry', European Management 
Review, 2, 198-211.

Lundin, R.A. and A. Söderholm (1995), 'A theory of the temporary organization', Scandinavian Journal of Management, 11(4),437-55.

Menger, P.-M. (1999), 'Artistic labor markets and careers', Annual Review of Sociology, 25, $541-74$

Neumann, W.L. (2000), Social research methods. Qualitative and quantitative approaches, 4th ed., Needham Heights: Allyn and Bacon.

Oakley, K. (2004), 'Not so cool Britannia: the role of the creative industries in economic development', International Journal of Cultural Studies, 7(1), 67-77.

Osterman, P. (1987), 'Choice of employment systems in internal labor markets', Industrial Relations, 26, 46-67.

Packendorff, J. (1995), 'Inquiring into the temporary organization: New directions for project management research', Scandinavian Journal of Management, 11(4), 319-33.

Paul, A. and A. Kleingartner (1994), 'Flexible production and the transformation of industrial relations in the motion picture and television Industry', Industrial and Labor Relations Review, 47, 663-78.

Penrose, E.G. (1980), The theory of the growth of the firm, 2nd ed., Oxford: Blackwell.

Petersen, R.A. and D.G. Berger (1971), 'Entrepreneurship in organizations: Evidence from the popular music industry', Administrative Science Quarterly, 16, 97-106.

Petersen, R.A. and D.G. Berger (1975), 'Cycles in symbol production: The case of popular music', American Sociological Review, 40, 158-73.

Pratt, A.C. (2005), 'New media: work organisation and place', paper presented at 23rd Annual International Labour Process Conference, Glasgow.

Randle, K. and N. Culkin (2009), 'Getting in and getting on in Hollywood: freelance careers in an uncertain industry', in A. McKinlay and C. Smith (eds) Creative labour, London: Palgrave, pp. 93-115.

Rauterberg, H. (2006), 'Heiß auf Matisse', DIE ZEIT, 17, 17-20.

Rüling, C. and J. Strandgaard Pedersen (2010), 'Film festival research from an organizational studies perspective', Scandinavian Journal of Management, 26, 318-23.

Sgourev, S. (2011), “'Wall Street" Meets Wagner: Harnessing Institutional Heterogeneity', Theory and Society, 40(4), 385-416.

Skillset (2008), Feature film production. Workforce survey report 2008, London: Skillset. 
Skillset (2010), Creative media workforce survey, London: Skillset.

Stanworth, C. and J. Stanworth (1997), 'Managing an externalised workforce: freelance labour-use in the UK book publishing industry', Industrial Relations Journal, 28(1),4355.

Starkey, K., C. Barnatt and S. Tempest (2000), 'Beyond networks and hierarchies: Latent organizations in the U.K. television industry', Organization Science, 11(3), 299-305.

Sutton, R. (2001), 'The weird rules of creativity', Harvard Business Review, 79(8), 94-103.

Sutton Trust (2006), The educational background of leading journalists, London: Sutton Trust.

Svejenova, S. (2005), "The path with the heart": Creating an authentic career', Journal of Management Studies, 42(5), 947-74.

Sydow, J. and U. Staber (2002), 'The institutional embeddedness of project networks: The case of content production in German television', Regional Studies, 36(3), 215-27.

Timm, T. (2007), 'Atelierbesuch Jeff Koons', ZEITmagazin Leben, 38, 46-8.

Thompson, P., M. Jones and C. Warhurst (2007), 'From conception to consumption: Creativity and the missing managerial link', Journal of Organizational Behavior, 28(5), $625-40$

Weber, M. (1922/1972), Wirtschaft und Gesellschaft, Tübingen: Mohr (1st ed. 1922; 5th ed. 1972).

Wijnberg, N.M. and G. Gemser (2000), 'Adding value to innovation: Impressionism and the transformation of the selection system in visual arts', Organization Science, 11(3), $323-9$.

Windeler, A. and J. Sydow (2001), 'Project networks and changing industry practices collaborative content production in the German television industry', Organization Studies, 22(6), 1036-60. 